\title{
The Abandonment Of Rural Old Towns: Moratalla, Murcia
}

\author{
Pascual A. López Sánchez \\ UCAm,palopez@ucam.edu \\ Fco. José Sánchez Medrano \\ UCAM, fjsanchez@ucam.edu \\ Joaquín J. Pastor Pérez \\ Universidad Miguel Hernández de Elche
}

\begin{abstract}
The demographic problem is one of the most troubling issues in today's society. The tendency of human concentration in big cities promotes the continuing exodus of rural communities what, added to the deficit of services and amenities of our old towns, leads to a situation of progressive abandonment. The current need to provide our buildings with an environmental adaptation offers some advantages in traditional construction, since some lessons in sustainable Mediterranean architecture underlie it and these may lead to interventions of revitalization of these areas.
\end{abstract}

Palabras Clave: Casco Antiguo, Arquitectura Sostenible, abandono, demografía.

Key words: old town, sustainable architecture, abandonment, demography.

\section{INTRODUCTION}

This paper describes the demographic problem related to the question of the progressive abandonment of the old centre of a town in Murcia ${ }^{1}$, Moratalla, and, at the same time, it shows how this problem affects vernacular architecture. This is one of the historic centres that remains less altered within its nearest environment ${ }^{2}$, in the region of Murcia.

Moratalla has a rich history of civilizations and cultures from prehistoric times until these days. Having more water resources than the rest of the region, it is located on the northwest district ${ }^{3}$. The area in question is located on a hill of 685 metres of altitude above sea level, a settlement of medieval origin with a clearly strategic defensive nature ${ }^{4}$.

\footnotetext{
1 Andrés Sarasa, José Luis; "El proceso desruralizador de la Región de Murcia: sus consecuencias". file://C:/Documents\%20and\%20Settings/48416647.ARQPDI34164/Mis\%20documentos/

Downloads/Dial net-ElProcesoDesruralizadorDeLaRegionDeMurcia-1173552.pdf.

2 Marcial García García:"Moratalla a través de los tiempos; historia de una Villa Santiaguista en el Reino de Murcia".

${ }^{3}$ Atlas de los Paisajes de la Región de Murcia http://massotti.carm.es/paisaje/publica/atlasmur/Atlas

PaisajeRegionMurcia.pdf.

4 Indalencio Pozo:"El Castillo de Moratalla, una fortificación emblemática de la Orden de Santiago: Intervención Arqueológica en el Fuerte Muros de la Villa". https://books.google.es/books? id=1lfp9W3oa50C Epg $=$ PA143Edq=Indalencio + Pozo+, + castillo+

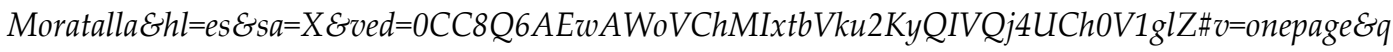
$=$ Indalencio $\% 20 \mathrm{Poz0} \% 20 \% 2 \mathrm{C} \% 20$ castillo $\% 20$ Moratalla $\mathcal{E} f=$ false.
} 
The group of houses around an Islamic fortress on an early Neolithic settlement is characterized by mimicry and strong adaptation to the particular promontory topography.

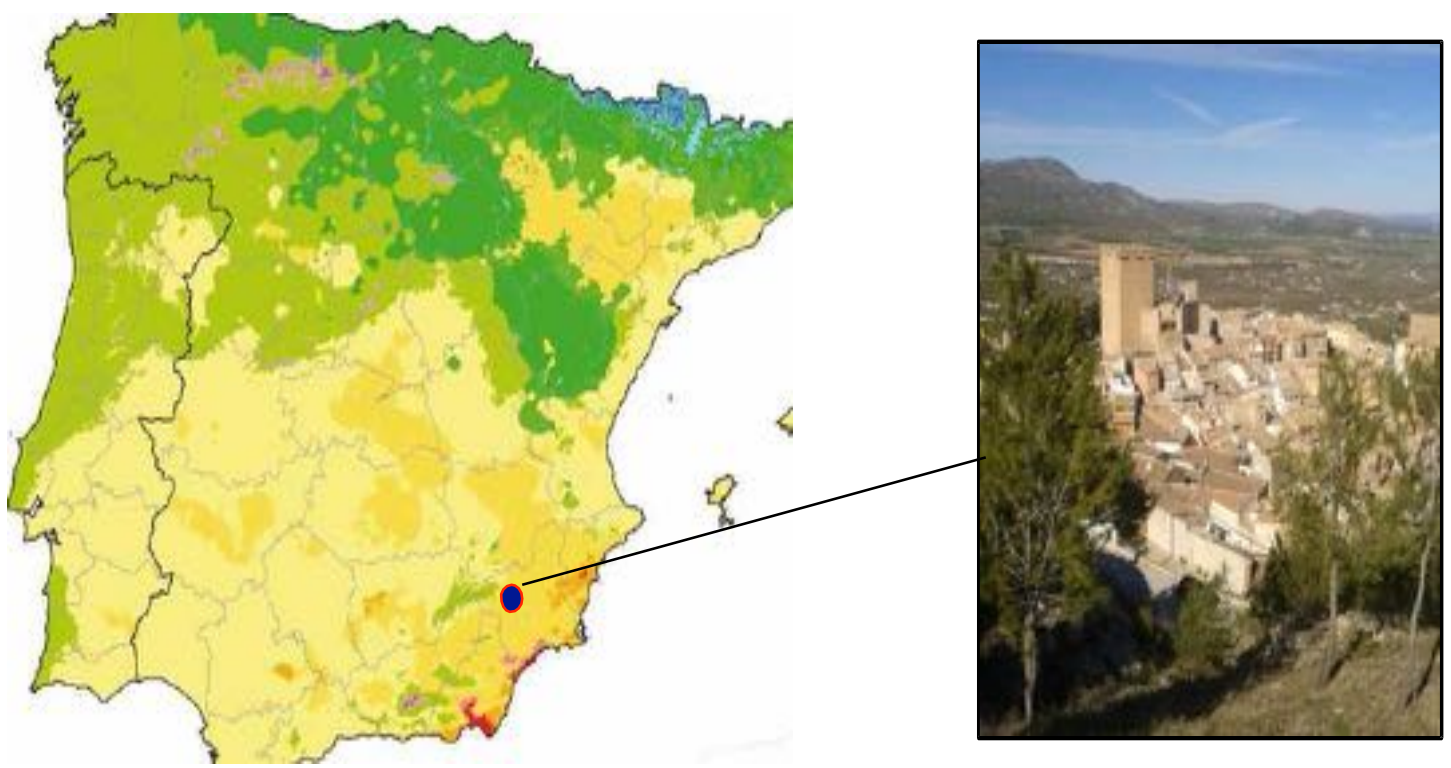

Figure 1. Location of Moratalla, Murcia

Its old town was delimited and classified for the first time in the last quarter of the twentieth century, coinciding with the modernization process of the Spanish political structures ${ }^{5}$, when actions were starting to be regulated and standardized with a certain degree of protection.

The old town occupies an area of about 135,000 m2, with winding streets, most of them being pedestrian, with significant slopes in many cases, what leads to stairs and buildings in different heights that take advantage of the steep gradient. It was originally domain of a few hundred inhabitants until accommodating inside its more than ten thousand people in its most flourishing stage ${ }^{6}$.

However, nowadays occupation of the old town has fallen sharply (50\% inhabited), being in a phase of decline of its built heritage. Most part of its buildings (265 under study) is residential, responding to a typology of vernacular construction since they were executed without prior layout and built by master builders. Hereinafter the level of abandonment and deterioration of the site will be studied, its causes and consequences as well as some suggestions to improve the described situation.

\footnotetext{
5 Muñoz Cosme, Alfonso: "Patrimonio Cultural de España: Arquitectura Tradicional".file://C:/Documents\%20and\%20Settings/48416647.ARQPDI34164/Mis\%20documentos/Do wnloads/14725.pdf.

"Francisco Chacón Jiménez, José Luis González Ortiz: "Bases para el estudio del comportamiento demográfico de Cehegín, Moratalla y Caravaca en la larga duración (1468-1930)". Pag.82.;https://digitum.um.es/xmlui/bitstream/10201/21919/1/05\%20Bases\%20para\%20el\%20estudio\% 20delcomportamiento\%20demografico $\% 20$ de\%20Cehegin\%20Caravaca\%20y\%20Moratalla.pdf.
} 
It is thought that $80 \%$ of the world population shall live in few years in large cities. To articulate this situation, public organisms are arranging regional polycentric developments ${ }^{7}$, which seek to compensate with more investment medium and small cities, generating areas that are more diversified and able to respond adequately to this phenomenon.

On the other hand, local architecture loses inherited techniques and modes in favour of a uniform and industrialized style ${ }^{8}$. By speaking about historical centres, the opportunity to recover those issues that are most environmentally friendly is given and this question may be an example of "green" actions related to culture and local tradition.

\section{State Of The Art}

The continued increase in the Spanish population since the nineteenth century has generated a continued increase in housing demand in Spain for a very long period that, in addition, was increased by countryside depopulation from the fifties of the last century and concentration of population in the centre and in sea areas $^{9}$.

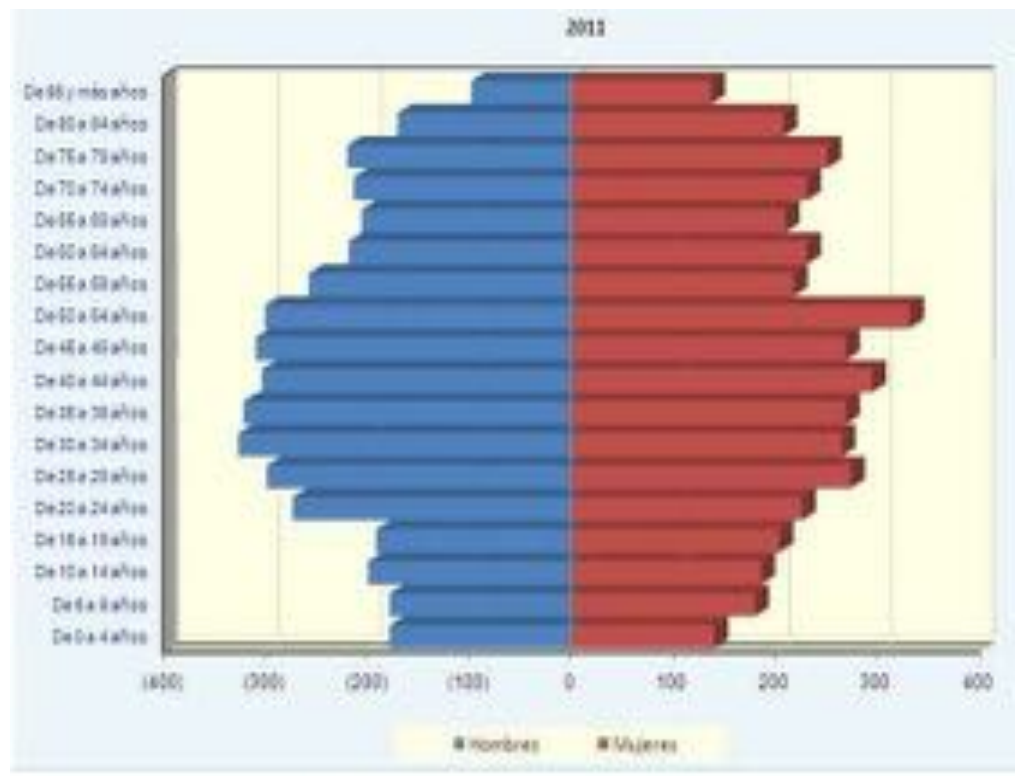

Figure $2^{10}$. Population pyramid in 2011 (Moratalla)

However, occupation of new land in Moratalla is not a direct result of substantial increase in population; from 1940, a cycle of significant decline began, from having 14,500 inhabitants to about half of them, around 8,000 inhabitants in 2014.

${ }^{7}$ Consejería de Obras Públicas y Ordenación del Territorio : "Directrices y Plan de Ordenación Territorial de
la
Comarca Murcia,pag.93.https://www.google.es/webhp? sourceid=chrome-instantEion=1Eespv=2Eie=UTF-

$8 \# q=s e g \% C 3 \% B A n+$ las + Directrices $+y+P l a n+d e+O r d e n a c i \% C 3 \% B 3 n+$ Territorial $+d e+l a+C o m a r c a+d e l+$ Noroeste+de+la+Regi\%C3\%B3n+de+Murcia\%2C+pag.+93.

${ }^{8}$ Marcial García García, José Ludeña López, José Jesús Sánchez Martínez:"Murcia Recupera, ¿...somos?... ¿qué fuimos?: Moratalla". Fundación Centro de Estudios Históricos e Investigaciones Locales de la Región de Murcia. Editora Regional CajaMurcia.ISBN:84-921128-4-0.

${ }^{9}$ http://habitat.aq.upm.es/lbl/a-lbl.es.pdf

$10 \quad$ file://C:/Documents\%20and\%20Settings/48416647.ARQPDI34164/Mis\%20documentos/Downloads/ 90103MORATALLA-Informe\%20Municipal\%202012\%20(1).pdf. 


\begin{tabular}{lrrrrrrrr} 
MUNICIPIO & 1900 & 1910 & 1920 & 1930 & 1940 & 1950 & 1960 & 1970 \\
\hline Fuente- & & & & & & & & \\
Alamo & 9.969 & 10.879 & 11.303 & 8.772 & 9.270 & 9.769 & 9.506 & 8.914 \\
Fortuna & $\mathbf{5 . 6 1 5}$ & 6.502 & 6.131 & 6.442 & 5.831 & 5.888 & 5.630 & $\mathbf{5 . 5 6 4}$ \\
Lorca & 69.836 & 70.807 & 74.696 & 60.300 & 69.639 & 70.998 & 58.641 & 60.609 \\
& & & & & & & $(6)$ & \\
Moratalla & 12.689 & 13.500 & 13.412 & 13.692 & 14.536 & 14.117 & 14.029 & 10.549 \\
Ojós & 1.277 & 1.323 & 1.228 & 1.190 & 1.346 & 1.151 & 1.159 & 894 \\
Ricote & 2.597 & 2.999 & 2.789 & 2.956 & 2.874 & 2.915 & 2.726 & 2.304
\end{tabular}

Figure 3. Basis for the study of demographic behaviour ${ }^{11}$

Regarding "pedanías" (dependant villages), the process of population decline is similar:

\begin{tabular}{|c|c|c|}
\hline PEDANÍA (DEPENDANT VILLAGE) & POPULATION IN 1950 & POPULATION IN 1991 \\
\hline ARENAL & 589 & 1 \\
\hline BÉJAR & 285 & 131 \\
\hline BENÁMOR & 116 & 1.0 \\
\hline BENIZAR & 1.2 & 297 \\
\hline CAÑADA DE LA CRUZ & 1.002 & 60 \\
\hline COBATILLAS & 547 & 78 \\
\hline INAZARES & 28 & 38 \\
\hline RIO SEGURA & 463 & 75 \\
\hline ROBLE & 501 & 17 \\
\hline ROGATIVA & 316 & 807 \\
\hline S. BARTOLOME & 1.112 & 383 \\
\hline S. JUAN & 871 & 17 \\
\hline
\end{tabular}

Figure $4^{12}$. Population data of "pedanías" (dependant villages) in Moratalla

Territory is a finite and non-renewable resource, hard to be recycled when urbanized and built, hardly recoverable for any other use once it has been devoted to housing. Developmentalism provided models of territorial, urban and constructive development, scarcely involved in environmental integration and with high consumption of resources.

One of the serious problems of our country is to solve the management of real estate heritage, in many cases, low quality, inefficiently used and quite oversized.

11 Francisco Chacón Jiménez, José Luis González Ortiz; Bases para el estudio del comportamiento demográfico de Cehegín, Moratalla y Caravaca en la larga duración (1468-1930), Pag.82.

;https://digitum.um.es/xmlui/bitstream/10201/21919/1/05\%20Bases\%20para\%20el\%20estudio\%2 0delcomportamiento\%20demografico $\% 20 \mathrm{de} \% 20$ Cehegin $\% 20$ Caravaca $\% 20 \mathrm{y} \% 20 \mathrm{Moratalla}$.pdf

12 file://C:/Documents\%20and\%20Settings/48416647.ARQPDI34164/Mis\%20documentos/Downloads/ 90103MORATALLA-Informe\%20Municipal\%202012\%20(1).pdf. 
Traditional architecture in our country has a long history of study that can be traced back to its origins in the sixteenth and seventeenth centuries ${ }^{13}$, although the really detailed one appeared in the eighteenth century to the present day.

- First, the Royal Decree-Law of $1926^{14}$ appears with special reference to the Second Title of "Protection and conservation of historical and artistic architectural riches of Spain and typical character of towns and cities," where obligation to protect buildings or sets of constructions is established, with reference to the term (now discarded) "typical" or "picturesque", which would accommodate the conservation of the aforementioned buildings.

- Second, we should mention the Law for the "Defence, conservation and enhancement of national artistic heritage" of 1933 (valid until 1985) ${ }^{15}$, whose Article 33 refers to the declaration of historic areas, not only in urban centres but also in rural ones, considering everything or parts of them.

- Third, we can find the Law on Land Use and Urban Planning of $1956^{16}$, promoted by architect Pedro Bidagor, whose Article 60 suggests the need and possibility of recovering buildings of special value, referring as well to the concept of tradition.

- Fourth, Order of November 20th, $1964{ }^{17}$ for the "Regulation of the Historical and Artistic sites" with special reference to interest representing these sites from the point of view of tourism (art. 5), to which it is recommended to keep traditional systems (art. 7).

We see therefore the growing interest that these architectures acquire from the cultural point of view and their contribution as a true activity worthy of being preserved.

- Fifth, we find Decree 449/1973 of February 22nd ${ }^{18}$, establishing the protection of "hórreos" or "cabazos" (granaries) in Asturias and Galicia over 100 years.

- Next, with the establishment of democracy in Spain, in the 1970s, the terms "typical" and "picturesque" were definitively abandoned to strengthen cultural values, contextualizing great monuments and recreating spaces that imply a monumental heritage.

- From those times, we can mention, on the one hand, the Declaration of Amsterdam of $1975^{19}$ (21-25 October), enhancing and expanding the concept of heritage, what means the homogeneity of style and the imprint of a human group; and, on the other hand, the

\footnotetext{
13 Agricultura Genera 1513, Gabriel Alonso de Herrera (1470-1539); o Acerca de los secretos de Agricultura, casa de campo y pastori 1617, Fray Miguel Agustín (1570-1630).

${ }^{14}$ Real Decreto-Ley relativo al Tesoro Artístico Arqueológico Nacional https://www.google.es/webhp ?sourceid=chrome-instant\&ion=1\&espv=2\&ie=UTF- 8\#q=real+decreto+ley+de+1926\%2C+Portec ci $\%$ C3\%B3n $\% 2 C+C o n s e r v a c i \% C 3 \% B 3 n+y+a c r e c e n t a m i e n t o+d e+l a+r i q u e z a+a r t \% C 3 \% A D s t i c a$ 15 Ley de 13 de mayo de 1933 sobre Defensa, Conservación y Acrecentamiento del Patrimonio Artístico Nacional 16 Ley del Suelo de 12 de Mayo de 1956 https://www.google.es/webhp?sourceid=chromeinstant\&ion=1\&espv=2\&ie=UTF-8\#q=Ley+del+Suelo+de+12+de+mayo+de+1956

17 Orden de 20 de Noviembre de 1964 http://www.e-coac.org/normativa/_nmt/Gen/E329.Pdf

18 Decreto 449/1973 de 22 de Febrero http://www.boe.es/diario_boe/txt.php?id=BOE-A-1973-361

${ }^{19}$ Declaración de Ámsterdam de 1975 http://ipce.mcu.es/pdfs/1975_Declaracion_Amsterdam.pdf
} 
Convention for the Protection of Architectural Heritage of Europe ${ }^{20}$ (Granada, October 3rd, 1985), recognizing in both cases vernacular architecture as cultural heritage.

- Then, the Law of 16/85 of Spanish Historical Heritage ${ }^{21}$, which represents a basic document to guide the different regional laws where regulation to be followed is set in historic sites, regarding treatment of surroundings, uses and definition of areas of restoration. Specifically article 21 refers to the preservation of its urban pattern and regards intervention only in case of danger by degradation. Particularly sections II and IV refer to ethnographic heritage, movable and immovable, considering traditional architecture not only for its cultural value but because of acquired, rooted and transmitted knowledge (art. 47), traditionally used by a community, being this reflected in community laws, such as the one of the region of Murcia.

- The autonomic law 4/2007, called the Law of Cultural Heritage of the Autonomous Community of Murcia ${ }^{22}$, refers to the concept of "ethnographic" and, specifically in Chapter II, art. 37, the protection regime to be established in protected areas prevails over urban planning and actions shall take place exclusively under the tutelage of the corresponding general direction.

In art. 44, we can find the special protection regime of a special Plan of Area Protection to be written by each local government, whose main objective is to preserve and facilitate the study and enjoyment for both current and future generations.

In art. 61. mandatory and executive plans are established, and title $\mathrm{V}$, art. 66. mentions specifically the consideration of traditional culture and own ways of life.

- Law 45/2007 of Sustainable Development of Rural Environment ${ }^{23}$ mentions in art. 33 the reuse and restoration of houses and buildings preserving rural architecture, catalogues to be developed for that purpose.

- Law 4/1990 of Measures of Historical Heritage Development of the Region of Murcia, where $1 \%$ cultural appears in works of some entity to be devoted to issues of cultural interest.

- In the Legislative Decree 1/2005, restated text of the Land Law of the Region of Murcia ${ }^{24}$, updated and revised real estate catalogues are cited, three degrees of protection being established: roughly, level 1 or integral protection, level 2, referred to minor works without compromising space or structure and level 3 , that allows a higher degree of modification.

Thus, in Murcia there are nine officially declared Historical Sites, standing out from the point of view of traditional architecture the one in Aledo (R.D. 964/1988), although in terms of environmental uniformity the case of Moratalla is remarkable.

\footnotetext{
20 Convenio para la Salvaguarda del Patrimonio Arquitectónico de Europa http://ipce.mcu.es/pdfs/1985_Convencion_Granada.pdf

${ }^{21}$ Ley de 16/85 de Patrimonio Histórico Español http://ipce.mcu.es/pdfs/ley16-1985.pdf

22 Ley 4/2007 denominada Ley de Patrimonio Cultural de la Comunit Autónoma de Murcia http://museoarqua.mcu.es/web/uploads/ficheros/ley4-2007.pdf

${ }^{23}$ Ley 45/2007 de Desarrollo Sostenible del Medio Rural http://www.boe.es/boe/dias/2007/12/14/pdfs/A51339-51349.pdf

${ }^{24}$ Ley 13/2015, de 30 de Marzo, de ordenación territorial y urbanística de la Región de Murcia https://www.boe.es/boe/dias/2015/05/01/pdfs/BOE-A-2015-4790.pdf
} 


\section{METHODOLOGY}

These data have been drawn from a study of the old town of Moratalla, where an exhaustive analysis of configuring elements of vernacular architecture is done, as well as, as associated item, the current level of occupation and habitability or abandonment.

It has been carried out a check by means of field records $(265)^{25}$ and details of configuring solutions of the urban landscape (100), as well as a search in the archives and municipal agencies, such as cadastre service ${ }^{26}$.

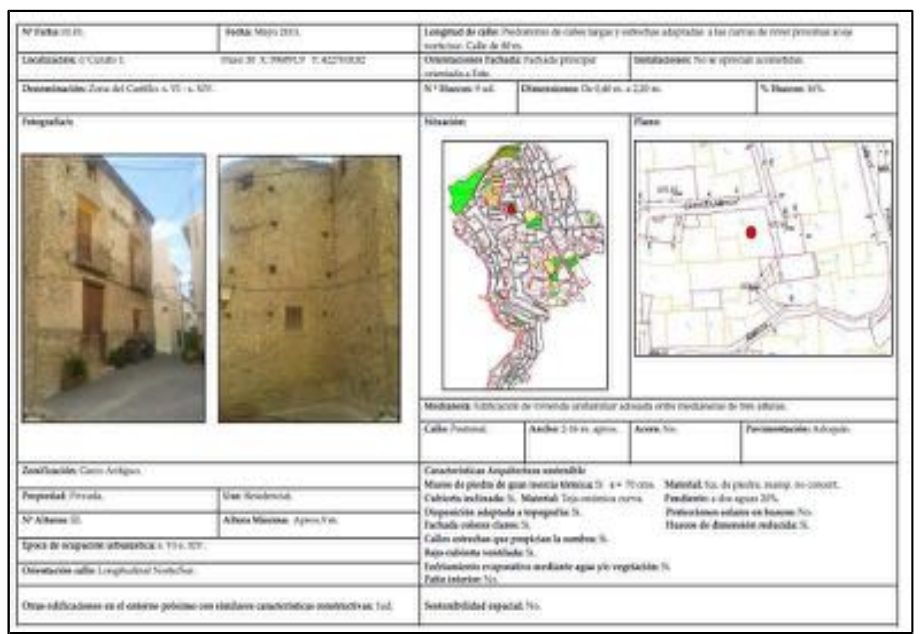

Figure 5. Field records of case study (own photo)

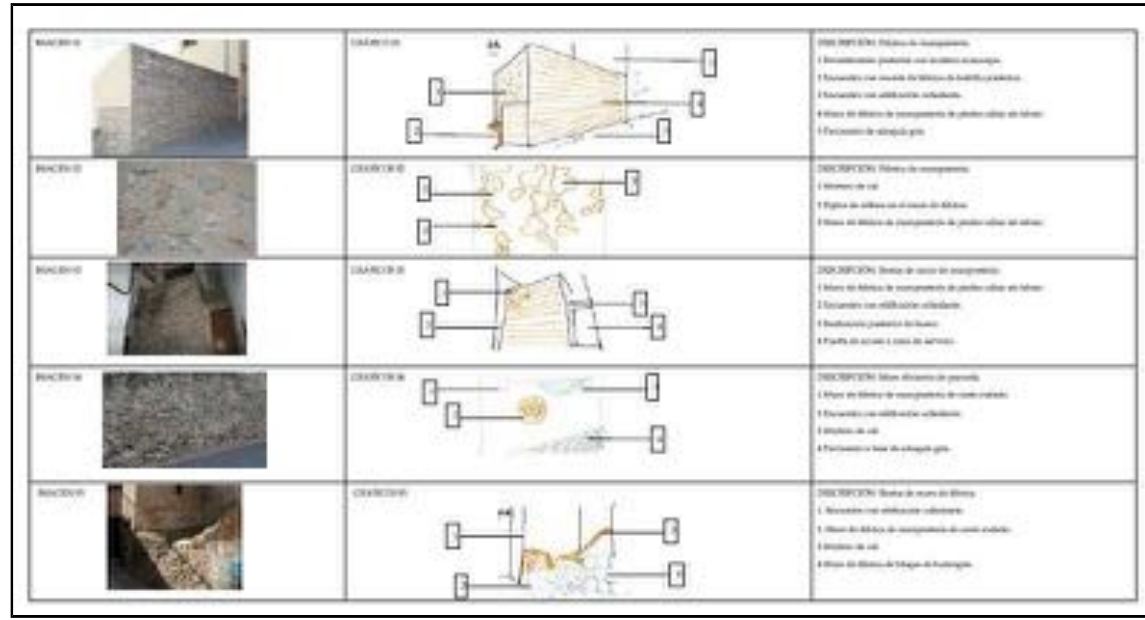

Figure 6. Description of urban landscape (own photo)

25 Pascual A. López Sánchez, Fco. José Sánchez Medrano: "Impacto de sostenibilidad en la arquitectura tradicional: el caso de Moratalla, Murcia http://aulagreencities.coamalaga.es/wp-content/uploads/2014/10

139.-ARQUITECTURA-TRADICIONAL.pdfhttp://www.coaatmu.es/descargas/articulo_Pascual_Lopez

_Arquitectura_sostenible.pdf

${ }^{26}$ Ayuntamiento de Moratalla: http://www.ayuntamientomoratalla.com/ 


\section{DATA ANALYSIS}

We should point out an index of dilapidated, abandoned or uninhabited buildings, showing an overview of the issue. Also, we highlight the absence of facilities, services or traffic problems that involve a comparative disadvantage with the expansion areas of the town.

In ruins, with official declaration, we find the following buildings in the old town of Moratalla, corresponding to the following locations:
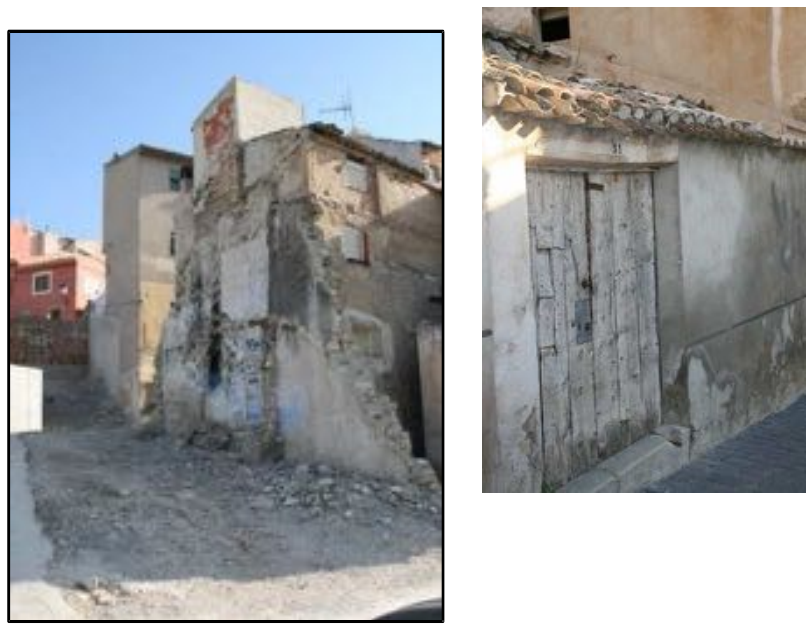

\section{Figure 7. Image of dilapidated edification (own photo)}

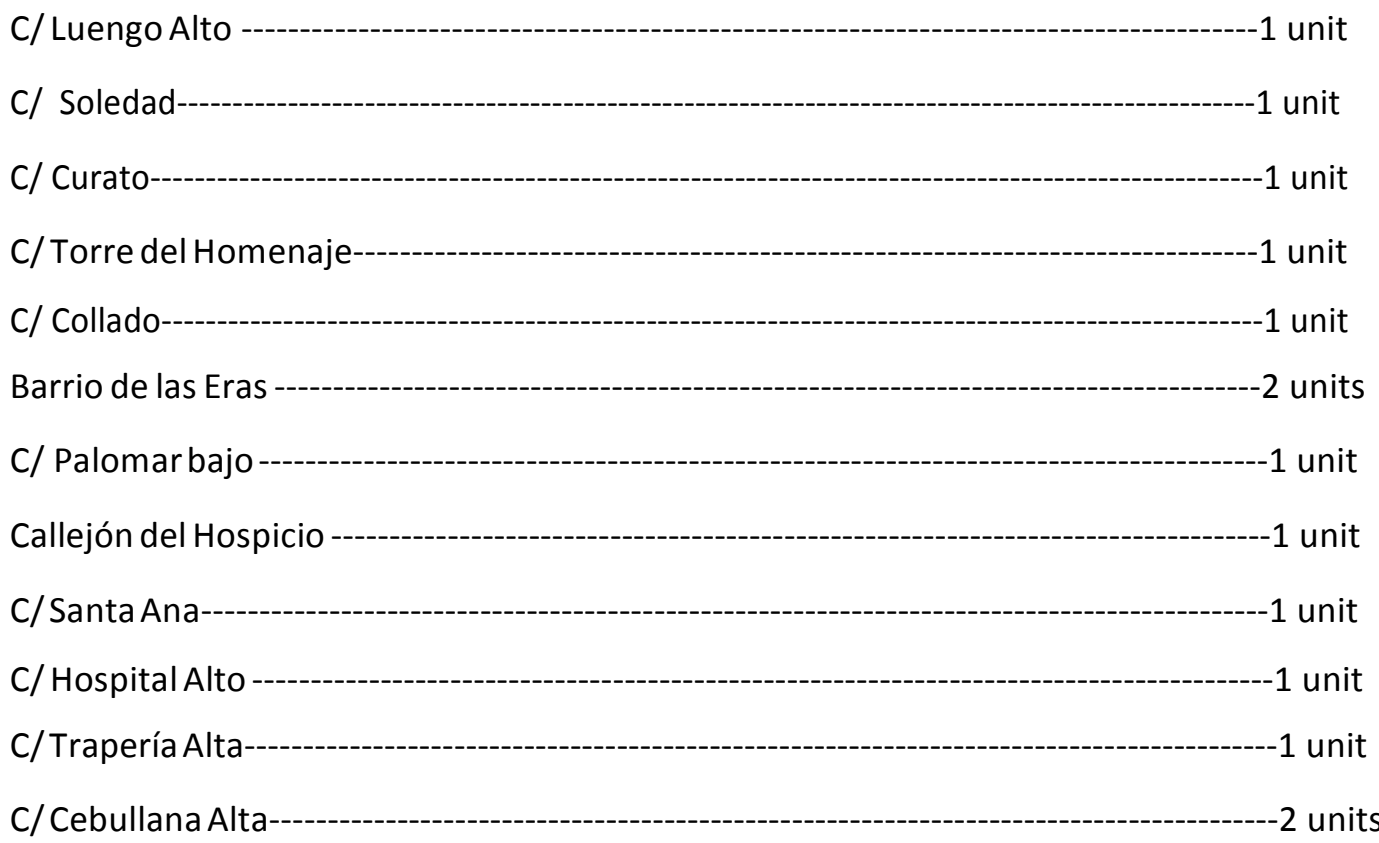

Total-14 units 
On the other hand, in a situation of lack of registered residents in buildings, the following ones can be found:
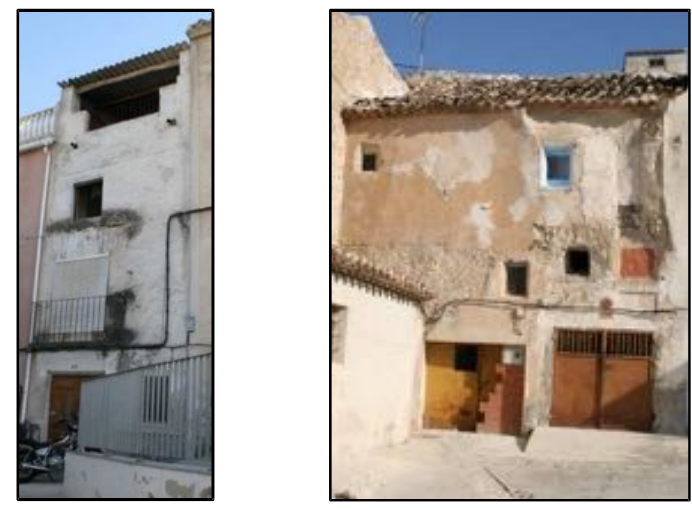

Figure 8. Images of buildings with no registered residents (own photo)

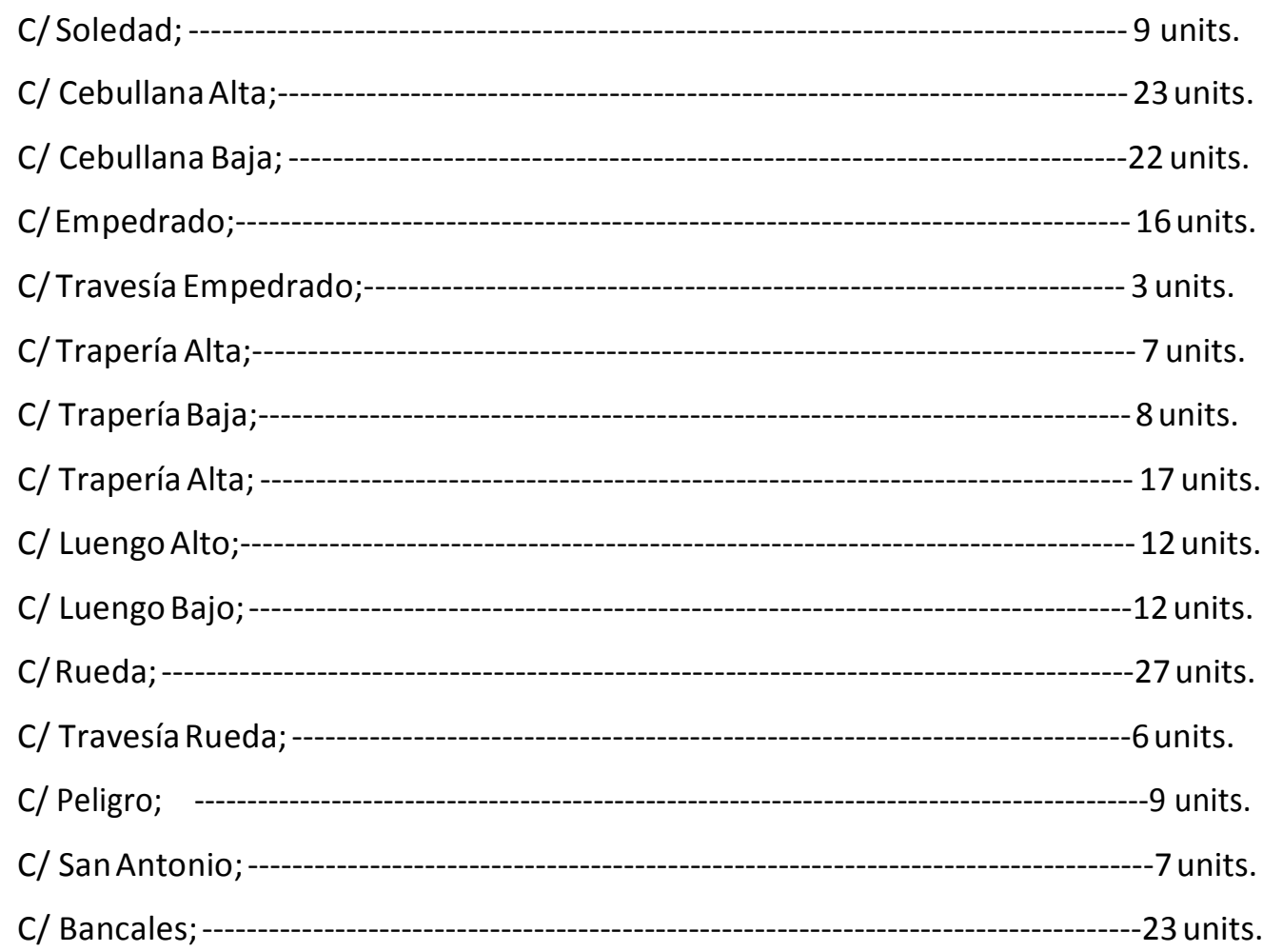
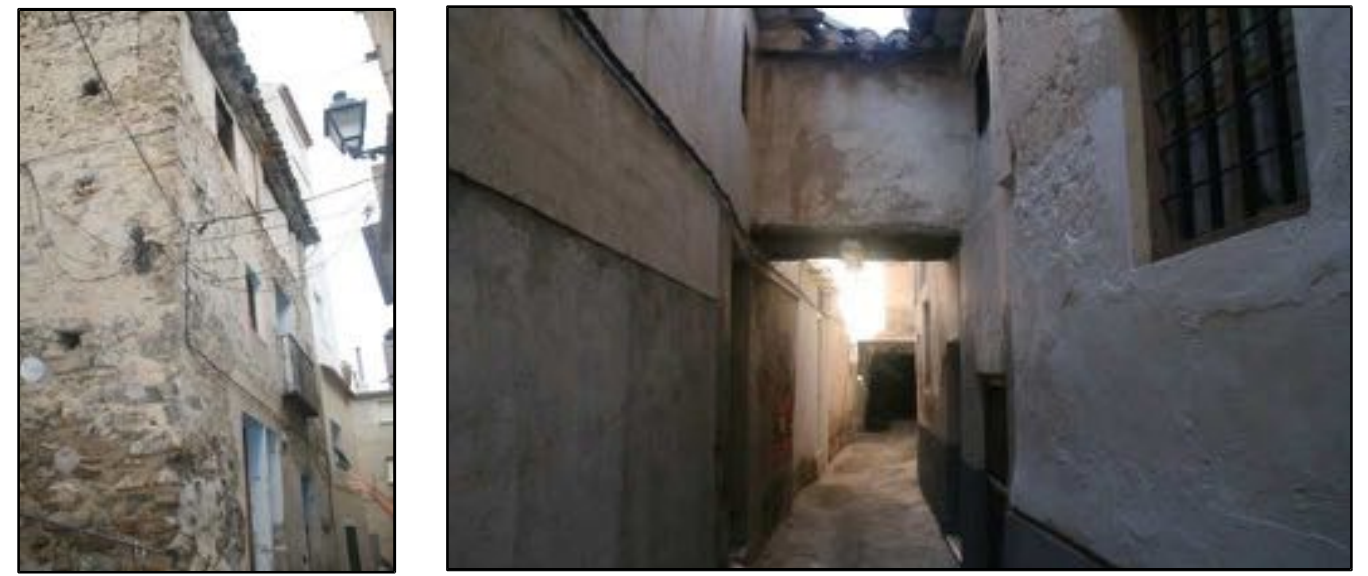

Figure 9. Out-dated edifications (own photo) 


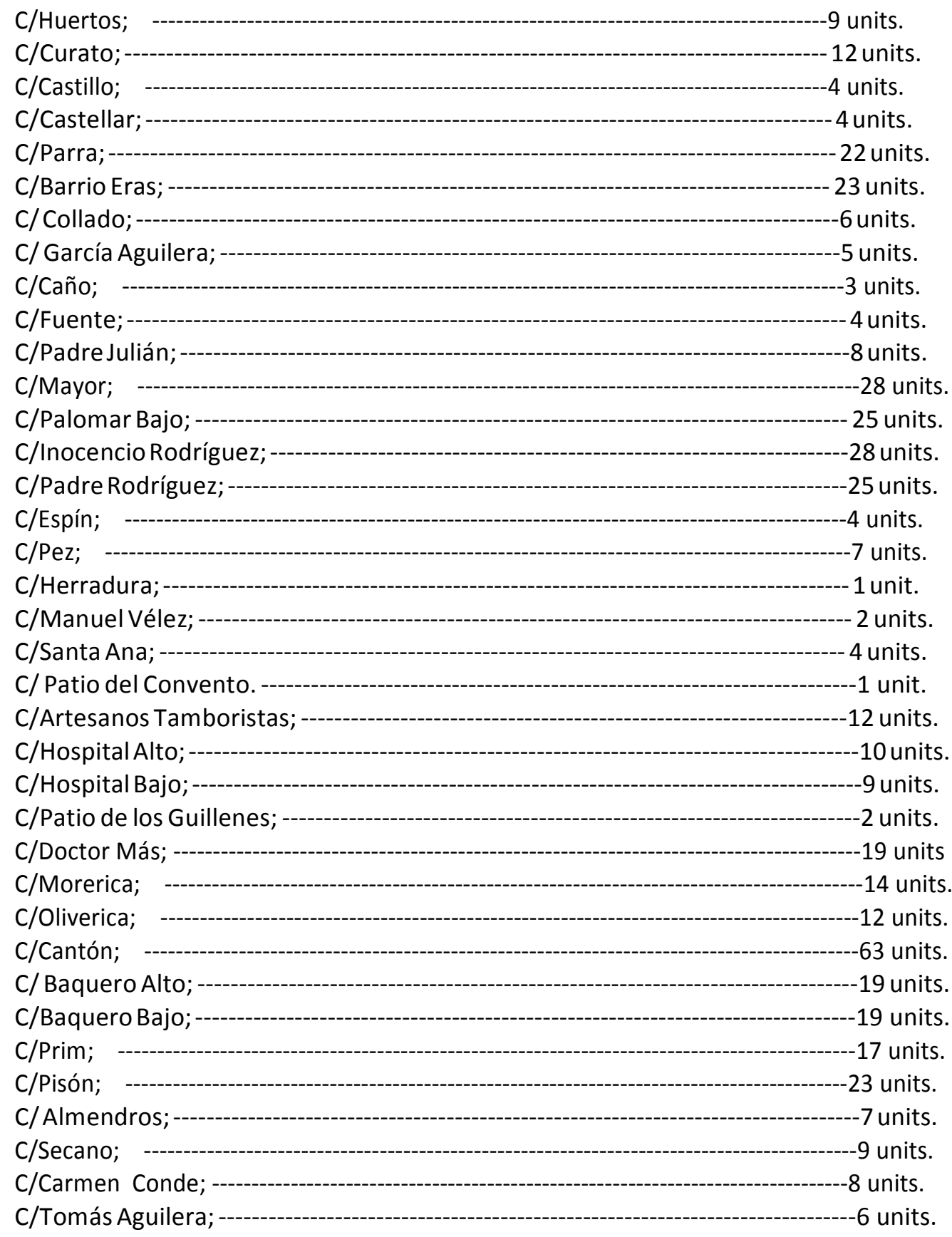

Total-685 units.

On the other hand, we see how commercial facilities have moved outside the old town, occupying areas with better road traffic, sharing this area with the population that has had the opportunity to move, representing an important proportion. 


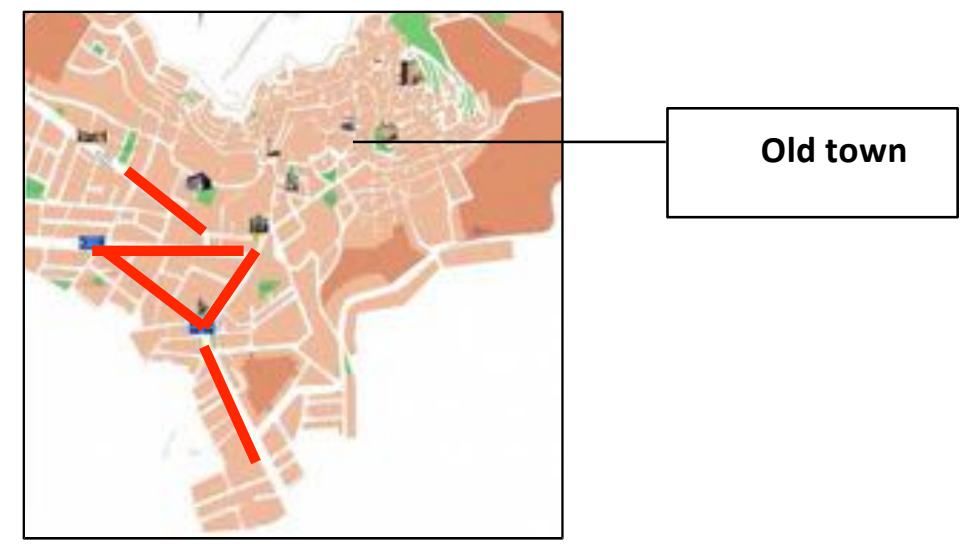

Figure 10. Exemplification of roads ( ) grouping commercial establishments (municipal source $)^{27}$

The old town, despite concentrating the "traditional" facilities (Local Council, Library, Trieta Theatre, Civil Guard Barracks, Santa María de la Asunción Church and Convent of San Francisco), highlights for the lack of other centres that provide most demanded services by today's society: health and public services, leisure, professional offices, etc.

The most important activity of this part is currently focused on local festivities: Easter, running of bulls on the occasion of local holidays, being underused the rest of the year. At a residential level, occupancy is around $50 \%$, reflecting the limited attractiveness that it represents, but which in turn offers a scenario of opportunities for intervention.

We find an old town able to accommodate a huge number of population, little altered by industrializing processes and decaying by movements of moving to more spacious and comfortable areas. These are new sites that have other deficits: loss of identity, building of less sustainable features, reduction in social relations, etc.

This situation provides an opportunity to inventory, document and preserve a built heritage rich in nuances, full of tradition, popular culture and environmental and landscape values that have been taken up as the essence of the ability to use natural resources. Restoration would serve as a mechanism of recovery of these anonymous architectures in their different scales, where special importance is given to planning instruments related to sustainability. 


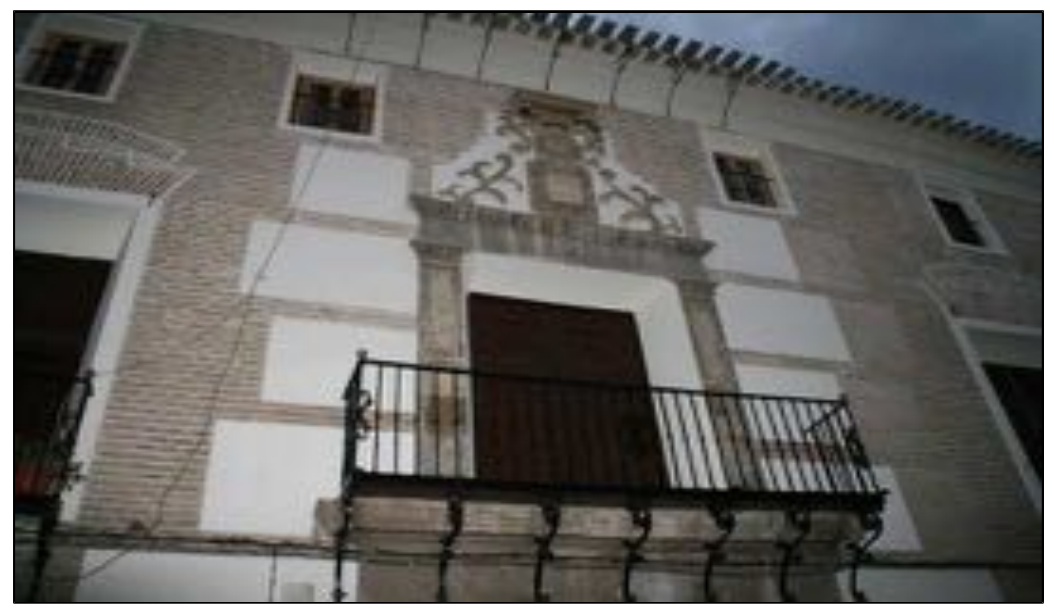

Figure 11. Restored building in the old town of Moratalla (own photo)

The treatment of roads, provision of parking spaces, of loading and unloading areas, and the possibility of access by vehicles, to facilitate the occupation by child and elderly population, should be subject to a particularized analysis, which encourages a rational integration of communications, as it has happened in old urban towns of similar characteristics (such as the case of Cehegín), removing the first obstacle that represents the current limitation of transportation.
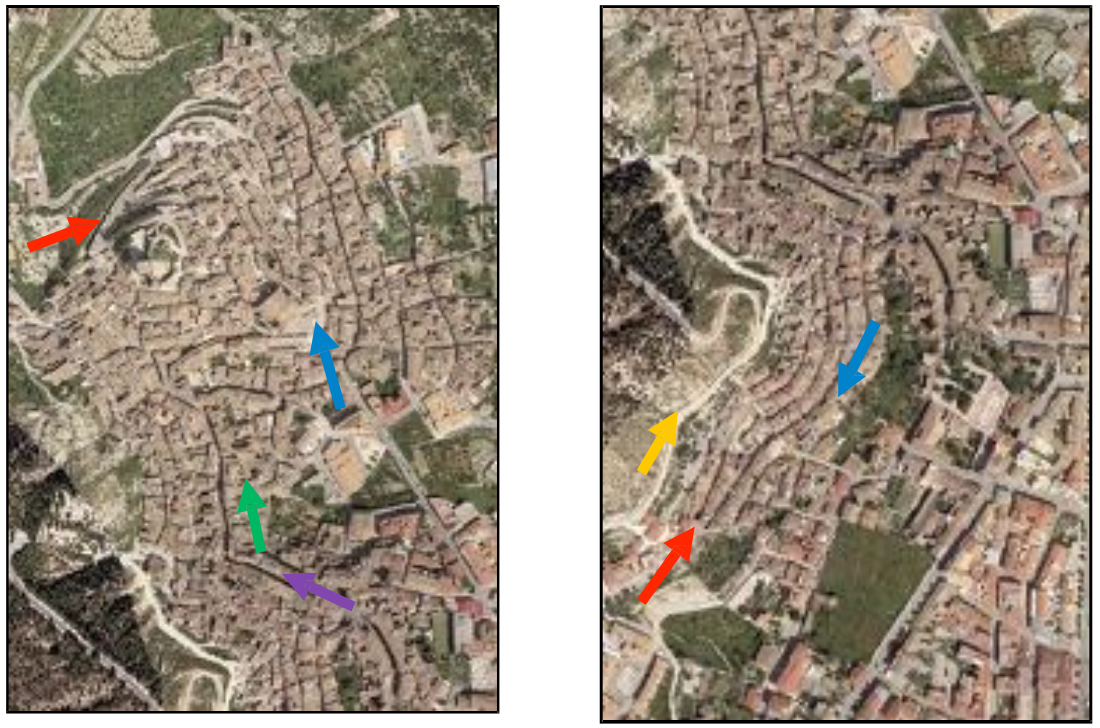

Figure 12. Vehicular access to the old town of Moratalla (own photo)

As it is shown in the graphic diagram in figure 12, the roads that allow vehicular access to the old town are very rare, circulation by vehicles being limited, practically with no parking space, for residents or visitors, what has generated in users a determining factor for its abandonment. This issue also affects negatively when attracting people as a tourist or landscape reference. 


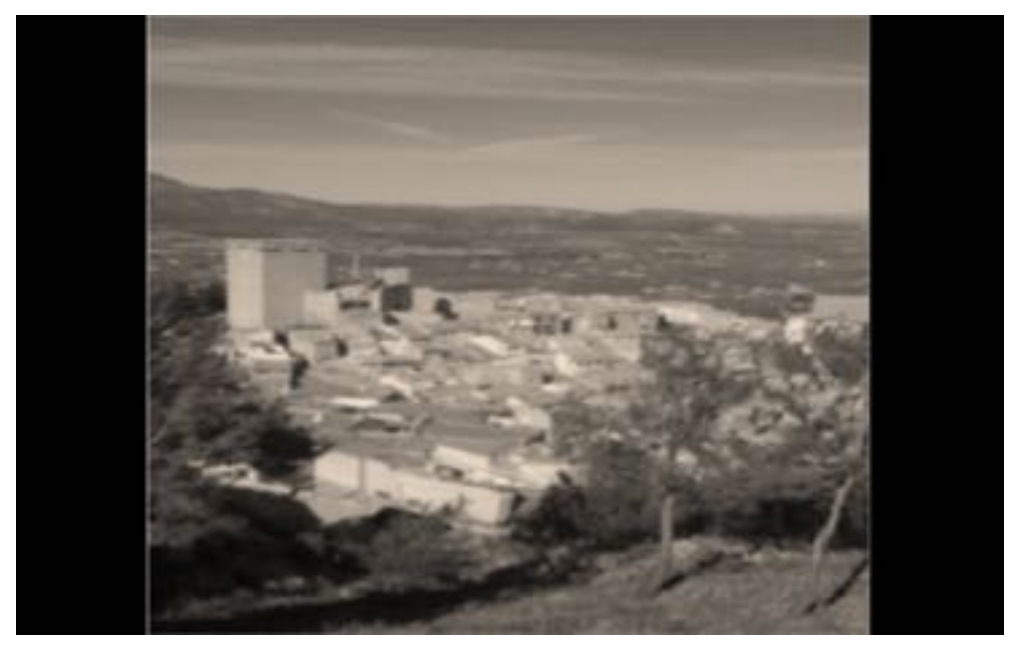

Figure 13. Panoramic view of the old town of Moratalla (own photo)

Achieving a revitalization of the old town would mean taking advantage of the indications of protectionist measures (for example, the ICOMOS Charter of $1999^{28}$ which states: "The Vernacular built Heritage is the natural and traditional way in which communities have produced their own habitat. It is part of a continuing process, including necessary changes and a continuous adaptation as a response to social and environmental requirements"). It will also be a true commitment to sustainability regarding the exploitation of the urban services that have been implemented for decades (paving roads, water, energy and communications supply, evacuation, lighting, etc.), as well as their own constructions provided with a set of passive measures and efficiency highly recognized nowadays: thermal inertia of walls, roofs, eaves, size and treatment gaps, etc.

Promoting its conservation and maintenance shall contribute to enhance sustainability in the whole town, reinforcing the idea of compact Mediterranean town against dispersed urban developments.

\section{CONCLUSIONS}

Anonymous vernacular architecture may have a natural continuity in evolution towards a sustainable way of living. Such continuity demonstrates an adaptation and survival capacity necessary in any aspect of our society.

An intervention based on respect for environment could lead to the necessary activation lever of the old towns that are victims of a process of abandonment.

Restoration against new construction may be promoted, providing a type of architecture coinciding better with the environment and climate of the area, versus the use of formal standardized parameters, profitability through income and not capital gains and energy savings compared to the waste of resources. In the State Housing Plan of 2009-2012, the word "restoration" appears for the first time in line with the Leipzig Charter where underprivileged areas deserve special attention, and where energy efficiency, accessibility and use of renewable energy are highlighted.

\footnotetext{
${ }^{28}$ Carta del Patrimonio Vernáculo Construido (1999) http://www.icomos.org/charters/vernacular_sp.pdf
} 


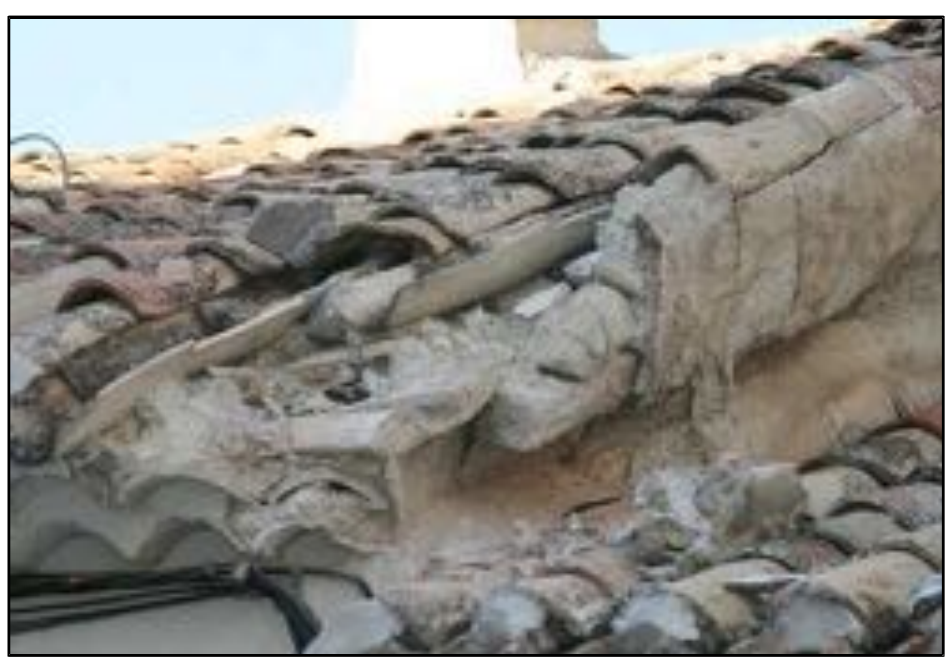

Figure 14. Image of start of roof deterioration in the old town (own photo)

In the Regional Plan for the same period major restoration aids are established, what has been accompanied by successive normative towards this new direction for the development of the sector.

The Land Law 8/2007 faced the necessary modification, its explanatory memorandum explaining that it was essential to adopt a new model in which the environmental value of rural land would be weighed. The demographic decline accusing our country (to which the collapse of net migration following the recent crisis is linked) offers an unprecedented opportunity to overcome the dogma of growth where urbanism, construction and real estate business have been settled in Spain so far.

Recently, it is stated in the Housing Law 6/2015 ${ }^{29}$, of March, 24, of the Region of Murcia that: "Sustainable and energy-efficient housing shall be ensured by environmental order, and the promotion of water conservation and use of renewable energy, as well as achieving a balanced urban development, acting in the restoration of the existing built park, as an instrument for the revitalization of our cities."

It is not in vain that in the White Paper of Construction ${ }^{30}$ of the Region of Murcia, (intended for 2015-2025), these ideas of conservation and restoration are alluded, being committed to sustainable developments that balance the inequality between cities and towns.

The European Territorial Agenda $2020^{31}$ "Towards an integrating, intelligent and sustainable Europe of diverse regions" develops the European strategy and sets priorities, among which the following ones can be highlighted:

- Promoting a polycentric and balanced territorial development.

- Fostering an integrated development of cities and rural and specific regions.

- Managing and connecting environmental, landscape and cultural values of regions.

${ }^{29} \mathrm{http}: / / w w w . b o r m . e s /$ borm/documento?obj=anuEid=728216

30 http://famdif.org/tag/libro-blanco-de-la-construccion/

31 http://www.cescanarias.org/documentos/atlantico/10_me_2011_agenda_territorial_europea_2020.pdf 
- Specifically, the Landscape Strategy of the Region of Murcia is also implemented where the following objectives are set:

- Awareness, training and education of society.

- Characterization and classification of landscapes.

- Recognition of landscape potential as an economic resource.

- Coordination between agents and stakeholders and tracking of the transformations.

In this respect, we demand from here the need to implement the wide proposed legislation to undertake the necessary restoration of the old town.

\section{BIBLIOGRAPHY}

ANDRÉS SARASA, JOSÉ LUIS; “El proceso desruralizador de la Región de Murcia: sus consecuencias". file:///C:/Documents\%20and\%20Settings/48416647.ARQPDI34164/Mis\%20doc umentos/Downloads/DialnetElProcesoDesruralizadorDeLaRegionDeMurcia- 1173552.pdf.

ALAVEDRA, P; DOMÍNGUEZ, J; GONZALO, E; SERRA, J: "La construcción sostenible. El estado de la cuestión". Informes de la Construcción, Vol. 49 no 451 (1997).

AGRICULTURA GENERA 1513, GABRIEL ALONSO DE HERRERA (1470-1539); o Acerca de los secretos de Agricultura, casa de campo y pastori 1617, Fray Miguel Agustín (1570-1630).

ATLAS DE LOS PAISAJES DE LA REGIÓN DE MURCIA

http://massotti.carm.es/paisaje/publica/atlasmur/AtlasPaisajeRegionMurcia.pdf

CARTA DEL PATRIMONIO VERNÁCULO CONSTRUIDO (1999)

http://www.icomos.org/charters/vernacular_sp.pdf.

CARTA DEL PATRIMONIO VERNÁCULO CONSTRUIDO (1999) http://www.icomos.org/charters/vernacular_sp.pdf CONFERENCIA DE LAS NACIONES UNIDAS SOBRE EL MEDIO HUMANO;

http://www.unep.org/geo/geo3/spanish/040.htm.

CONVENIO EUROPEO DEL PAISAJE.http://www.magrama.gob.es/es/desarrollo-rural/temas/desarrolloterritorial/090471228005d489_tcm7-24940.pdf.

CONVENIO PARA LA SALVAGUARDA DEL PATRIMONIO ARQUITECTÓNICO DE EUROPA

http://ipce.mcu.es/pdfs/1985_Convencion_Granada.pdf.

CONSEJERÍA DE OBRAS PÚBLICAS Y ORDENACIÓN DEL TERRITORIO:"Directrices y Plan de Ordenación

Territorial de la Comarca del Noroeste de la Región de

Murcia,pag.93.https://www.google.es/webhp?sourceid=chromeinstant\&ion=1\&espv=2\&ie=UTF-

$8 \# \mathrm{q}=\mathrm{seg} \% \mathrm{C} 3 \% \mathrm{BAn}+$ las+Directrices+y+Plan+de+Ordenaci $\% \mathrm{C} 3 \% \mathrm{~B} 3 \mathrm{n}+\mathrm{Territori}$

al+de+la+Comarca+del+Noroeste+de+la+Regi $\%$ C3\%B3n+de+Murcia\%2C+pag+93

FRANCISCO CHACÓN JIMÉNEZ, JOSÉ LUIS GONZÁLEZ ORTIZ: "Bases para el estudio del comportamiento demográfico de Cehegín, Moratalla y Caravaca en la larga duración (1468-1930)".

Pag.82.;https://digitum.um.es/xmlui/bitstream/10201/21919/1/05\%20Bases\%20para\%20el\%20estudio\%20de lcomportamiento\%20demografico\%20de\%20Cehegin\%20Caravaca\%20y\%20Moratalla.pdf.

FRANCISCA DEL BAÑO MARTÍNEZ:

https://www.upo.es/historia_arte/export/sites/historia_arte/Actividades/Congres

os/Publicacion_Arquitectura_Vernacula_Carmona/ComunicacionesEspana/Fra

ncisca_del_Bano_Martinez_Formas_y_usos_de_la_vivienda_tradicional_en_el_centro_de_la_region_de_Murcia.pdf.

GARCÍA NAVARRO, J.:"Buenas prácticas para la mejora del entorno urbano".Informes de la construcción. Vol. 55, núm.486, (2003).

INDALENCIO POZO:”El Castillo de Moratalla, una fortificación emblemática de la Orden de Santiago:

Intervención Arqueológica en el Fuerte y Muros de la 
Villa".https://books.google.es/books?id=1lfp9W3oa50C\&pg=PA143\&dq=Indalen cio+Pozo+,+castillo+Moratalla\&hl=es\&sa=X\&ved=0CC8Q6AEwAW oVChMIxtb Vku2KyQIVQj4UCh0V1glZ\#v=onepage\&q=Indalencio\%20Pozo\%20\%2C\%20ca stillo\%20Moratalla\&f=false.

JUAN B. VILAR.:"Murcia: De la emigración a la inmigración. Murcia. Fundación Centro de Estudios Históricos e Investigaciones Locales Región de Murcia”. 2002. 223

pp.https://digitum.um.es/xmlui/bitstream/10201/11703/1/N\%20\%206\%20de\%20Juan\%20B.\%20Vilar.pdf.

LEY DE 13 DE MAYO DE 1933 SOBRE DEFENSA, CONSERVACIÓN Y ACRECENTAMIENTO DEL PATRIMONIO ARTÍSTICO NACIONAL,https://www.google.es/webhp?sourceid=chrome-instant\&ion=1\&espv=2\&ie=UTF8\#q=Ley+de+13+de+mayo+de+1933+sobre+Defensa $\% 2 C+$ Conservaci $\%$ C3\%B $3 \mathrm{n}+\mathrm{y}+$ Acrecentamiento+del+Patrimonio+Art\%C3\%ADstico+Nacional

LEY DEL SUELO DE 12 DE MAYO DE 1956https://www.google.es/webhp?sourceid=chromeinstant\&ion=1\&espv=2\&ie=UTF8\#q=Ley+del+Suelo+de+12+de+mayo+de+1956.

LEY DE 16/85 DE PATRIMONIO HISTÓRICO ESPAÑOL http://ipce.mcu.es/pdfs/ley16-1985.pdf.

LEY 4/2007 DENOMINADA LEY DE PATRIMONIO CULTURAL DE LA COMUNIT AUTÓNOMA DE MURCIA http://museoarqua.mcu.es/web/uploads/ficheros/ley4-2007.pdf.

LEY 45/2007 DE DESARROLLO SOSTENIBLE DEL MEDIO RURAL http://www.boe.es/boe/dias/2007/12/14/pdfs/A51339-51349.pdf.

LEY 4/1990 DE MEDIDAS DE FOMENTO DEL PATRIMONIO HISTÓRICO DE LA REGIÓN DE MURCIA http://www.boe.es/diario_boe/txt.php?id=BOE-A-1990-16902.

MARCIAL GARCÍA GARCÍA, JOSÉ LUDEÑA LÓPEZ, JOSÉ JESÚS SÁNCHEZ MARTÍNEZ: "Murcia Recupera, ¿...somos?... ¿qué fuimos?:Moratalla". Fundación Centro de Estudios Históricos e Investigaciones Locales de la Región de Murcia. Editora Regional CajaMurcia.ISBN:84-921128-4-0.

MARCIAL GARCÍA GARCÍA:" Moratalla a través de los tiempos; historia de una Villa Santiaguista en el Reino de Murcia".

MUÑOZ COSME, ALFONSO: "Patrimonio Cultural de España: Arquitectura

Tradicional”.file:///C:/Documents\%20and\%20Settings/48416647.ARQPDI34164

/Mis\%20documentos/Downloads/14725.pdf.

ORDEN DE 20 DE NOVIEMBRE DE 1964,http://www.e-coac.org/normativa/_nmt/Gen/E329.Pdf.

ORIHUELA, ANTONIO: “La casa Andalusí un recorrido a través de su evolución”.

http://digital.csic.es/bitstream/10261/16403/1/2007\%20Artigrama\%2 0Casa\%20andalus.pdf.

PASCUAL A. LÓPEZ SÁNCHEZ, FCO. JOSÉ SÁNCHEZ MEDRANO: “Impactode sostenibilidad en la arquitectura tradicional: el caso de Moratalla, Murcia http://aulagreencities.coamalaga.es/wp-content/uploads/2014/10/39.ARQUITECTURA TRADICIONAL.pdfhttp://www.coaatmu.es/descargas/articulo_Pascual_Lopez_ Arquitectura_sostenible.pdf

POZO MARTÍNEZ, INDALENCIO: “El Castillo Fortaleza de Moratalla”.

PALACIOS ONTALVA SANTIAGO J.:"Los Libros de Visita de la Orden de Santiago: fuente para una Historia de la arquitectura militar".

REAL DECRETO-LEY RELATIVO AL TESORO ARTÍSTICO ARQUEOLÓGICO NACIONAL https://www.google.es/webhp?sourceid=chrome-instant\&ion=1\&espv=2\&ie=UTF8\#q=real+decreto+ley+de+1926\%2C+Portecci $\%$ C3\%B3n $\% 2 \mathrm{C}+$ Conservaci $\% \mathrm{C} 3 \% \mathrm{~B} 3 \mathrm{n}+\mathrm{y}+\mathrm{acrecentamiento}+\mathrm{de}+\mathrm{la}+\mathrm{riq}$ ueza+art\%C3\%ADstica. 